\title{
High quality draft genome sequence of an extremely halophilic archaeon Natrinema altunense strain $\mathrm{AJ} 2^{\top}$
}

\author{
Hong Cheng ${ }^{1,2} \mathbb{D}$, Ying-Yi Huo ${ }^{1}$, Jing $\mathrm{Hu}^{2}$, Xue-Wei $\mathrm{Xu}^{1 *}$ and Min $\mathrm{Wu}^{2^{*}}$
}

\begin{abstract}
Natrinema altunense strain $\mathrm{AJ}^{\top}$, a halophilic archaeal strain, was isolated from a high-altitude $(3884 \mathrm{~m})$ salt lake in Xinjiang, China. This strain requires at least $1.7 \mathrm{M} \mathrm{NaCl}$ to grow and can grow anaerobically in the presence of nitrate. To understand the genetics underlying its extreme phenotype, we de novo assembled the entire genome sequence of $A J 2^{\top}$ (=CGMCC $1.3731^{\top}=J C M 12890^{\top}$ ). We assembled $3,774,135$ bp of a total of $4.4 \mathrm{Mb}$ genome in only 20 contigs and noted its high GC content (64.6\%). Subsequently we predicted the gene content and generated genome annotation to identify the relationship between the epigenetic characteristics and genomic features. The genome sequence contains 52 tRNA genes, 3 rRNA genes and 4,462 protein-coding genes, 3792 assigned as functional or hypothetical proteins in nr database. This Whole Genome Shotgun project was deposited in DDBJ/EMBL/GenBank under the accession JNCS00000000. We performed a Bayesian (Maximum-Likelihood) phylogenetic analysis using $16 \mathrm{~S}$ rRNA sequence and obtained its relationship to other strains in the Natrinema and Haloterrigena genera. We also confirmed the ANI value between every two species of Natrinema and Haloterrigena genera. In conclusion, our analysis furthered our understanding of the extreme-environment adapted strain $\mathrm{A} J 2^{\top}$ by characterizing its genome structure, gene content and phylogenetic placement. Our detailed case study will contribute to our overall understanding of why Natrinema strains can survive in such a high-altitude salt lake.
\end{abstract}

Keywords: Halophilic archaea, High-altitude, Salt lake, Rhodopsin, Light-driven pumps

\section{Introduction}

When the genus Natrinema was first described in 1998, it contained two species, Natrinema pellirubrum and Natrinema pallidum [1]. The genus Natrinema belongs to family Halobacteriaceae, phylum Euryarchaeota. Five more species of this genus were isolated and characterized since then, including $N$. versiforme [2], N. altunense [3], $N$. gari [4], N. ejinorense [5] and N. salaciae [6]. For now, the genomic sequences of all but $N$. ejinorense and $N$. salaciae in the genus Natrinema are publicly available on Genomes Online Database [7] and/or NCBI Genbank. Our lab first identified the $N$. altunense strain $\mathrm{AJ} 2^{\mathrm{T}}$ in 2005 in a salt lake [3]. Living cells in salt lake have made numerous adaptations to this special ecosystem, allowing them to

\footnotetext{
*Correspondence: xuxw@sio.org.cn; wumin@zju.edu.cn

'Laboratory of Marine Ecosystem and Biogeochemistry, Second Institute of

Oceanography, State Oceanic Administration, Hangzhou 310012, People's Republic of China

${ }^{2}$ College of Life Sciences, Zhejiang University, Hangzhou 310058, People's Republic of China
}

flourish in a very harsh environment. To determine if the $\mathrm{AJ} 2^{\mathrm{T}}$ genome contains genes for adaptation to a particular set of environmental restrictions and supply a version of genome assembly in the database, we sequenced its whole genome in 2011 and published the whole genome sequence in the WGS database in May, 2014 as the first reported whole genome sequence of its species.

\section{Organism information}

We isolated the strain $\mathrm{AJ}^{\mathrm{T}}$ from a water sample collected from the edge of Ayakekum salt lake $\left(37^{\circ} 37^{\prime} \mathrm{N}\right.$, $89^{\circ} 29^{\prime} \mathrm{E}$ ) in Altun Mountain (Altyn-Tagh) National Nature Reserve in Xinjiang, China (Table 1). This salt lake is cold and exposed to strong ultraviolet radiation throughout the year due to its high altitude. It also has high salinity and lacks the common organic nutrients for microorganisms [3]. 
Table 1 Classification and general features of Natrinema altunense AJ2 ${ }^{\top}[11]$

\begin{tabular}{|c|c|c|c|}
\hline MIGS ID & Property & Term & Evidence code $\mathrm{a}^{\mathrm{a}}$ \\
\hline & Current classification & $\begin{array}{l}\text { Domain Archaea } \\
\text { Phylum Euryarchaeota } \\
\text { Class Halobacteria } \\
\text { Order Halobacteriales } \\
\text { Family Halobacteriaceae } \\
\text { Genus Natrinema } \\
\text { Species Natrinema altunense } \\
\text { Type strain AJ2 } 2^{\top}=\text { CGMCC } 1.3731^{\top}=J C M \quad 12890^{\top}\end{array}$ & $\begin{array}{l}\text { TAS }[32] \\
\text { TAS }[33,34] \\
\text { TAS }[33,35] \\
\text { TAS }[35,36] \\
\text { TAS }[37,38] \\
\text { TAS }[1] \\
\text { TAS }[3]\end{array}$ \\
\hline & Gram stain & - & TAS [3] \\
\hline & Cell shape & Rod & TAS [3] \\
\hline & Motility & Motile & TAS [3] \\
\hline & Sporulation & None & NAS [3] \\
\hline & Temperature range & Not reported & TAS [3] \\
\hline & Optimum temperature & Not reported & TAS [3] \\
\hline & pH range; Optimum & $5.5-9.0 ; 6.5-7.5$ & IDA \\
\hline & Carbon source & $\begin{array}{l}\text { Glucose, glycerol, maltose, glutamate, alanine, } \\
\text { arginine, lysine, ornithine, acetate, fumarate, } \\
\text { malate, propionate, pyruvate and succinate }\end{array}$ & TAS [3] \\
\hline MIGS-6 & Habitat & Salt lake & TAS [3] \\
\hline MIGS-6.3 & Salinity & $\begin{array}{l}\text { Extremely halophilic. Growth requires } 1.7 \mathrm{M} \\
\mathrm{NaCl} \text { (optimally } 3.0-4.3 \mathrm{M} \text { ) and grows in a } \\
\text { wide range of } 0.005-1.0 \mathrm{M} \mathrm{MgCl}_{2} \\
\text { (optimally } 0.05-0.2 \mathrm{M} \text { ). }\end{array}$ & TAS [3] \\
\hline MIGS-22 & Oxygen requirement & $\begin{array}{l}\text { Aerobic. But the isolate can grow anaerobically } \\
\text { in the presence of nitrate. }\end{array}$ & TAS [3] \\
\hline MIGS-15 & Biotic relationship & Free-living & NAS \\
\hline MIGS-14 & Pathogenicity & Not reported & \\
\hline MIGS-4 & Geographic location & $\begin{array}{l}\text { Altun Mountain National Nature Reserve in } \\
\text { Xinjiang, China }\end{array}$ & TAS [3] \\
\hline MIGS-5 & Sample collection & July, 2002 & NAS \\
\hline $\begin{array}{l}\text { MIGS-4.1 } \\
\text { MIGS-4.2 }\end{array}$ & $\begin{array}{l}\text { Latitude } \\
\text { Longitude }\end{array}$ & $\begin{array}{l}37.62^{\circ} \mathrm{N} \\
89.48^{\circ} \mathrm{E}\end{array}$ & $\begin{array}{l}\text { TAS [3] } \\
\text { TAS [3] }\end{array}$ \\
\hline MIGS-4.4 & Altitude & 3884 m & TAS [3] \\
\hline
\end{tabular}

${ }^{a}$ Evidence codes - IDA Inferred from Direct Assay, TAS Traceable Author Statement (i.e., a direct report exists in the literature); NAS Non-traceable Author Statement (i.e., not directly observed for the living, isolated sample, but based on a generally accepted property for the species, or anecdotal evidence). These evidence codes are from the Gene Ontology project [39]

\section{Classification and features}

$N$. altunense strain $\mathrm{AJ} 2^{\mathrm{T}}$ is an extremely halophilic archaea growing at $1.7-4.3 \mathrm{M} \mathrm{NaCl}$ and $0.005-1.0 \mathrm{M}$ $\mathrm{MgCl}_{2}$. Colonies in the agar plate have a vivid orange or red colour. Cells are rod-shaped, but can become pleomorphic under unfavourable conditions as reported in 2005 [3]. The 16S rRNA gene sequence analysis was submitted to the EzTaxon-e service [8] and revealed 95.77-98.50\% sequence similarity to members of the genus Natrinema. Strain $\mathrm{AJ}^{\mathrm{T}}$ exhibited the highest $16 \mathrm{~S}$ rRNA gene sequence similarity with $N$. gari HIS40-3 ${ }^{\mathrm{T}}$ (98.50\%). Phylogenetic analysis based on 16S rRNA gene sequences showed that strain $\mathrm{AJ} 2^{\mathrm{T}}$ clustered with most type strains of the genus Natrinema with a high bootstrap value (Fig. 1). The other three type strains, N. pellirubrum DSM $15624^{\mathrm{T}}, N$. salaciae $\mathrm{MDB} 25^{\mathrm{T}}$ and N. ejinorense $\mathrm{EJ}-57^{\mathrm{T}}$, were clustered with the genus Haloterrigena. In the $16 S$ rRNA gene trees (Fig. 1) and rpoB' (RNA polymerase subunit B') gene trees [9], these three type strains of genus Natrinema showed unclear taxonomic positions [10]. The mixture phylogenetic relationship between these strains in the Natrinema and Haloterrigena genera were reported in 2003 [9]. This suggests that Haloterrigena maybe a later synonym (heterotypic) of genus Natrinema. The cell morphology and flagellum of $N$. altunense strain $\mathrm{AJ}^{\mathrm{T}}$ were examined using transmission electron microscopy (JEM-1230, JEOL). The cells of strain $\mathrm{AJ} 2^{\mathrm{T}}$ are straight and rods and have a diameter ranging $0.3-0.8 \mu \mathrm{m}$ and length of $0.9-$ $4.0 \mu \mathrm{m}$ (Fig. 2). The cells are motile and their growth requires at least $1.7 \mathrm{M} \mathrm{NaCl}$ and $0.005-1 \mathrm{M} \mathrm{MgCl}_{2}$ (optimal 3.0-4.3 M NaCl and 0.05-0.2 $\mathrm{M} \mathrm{MgCl}_{2}$ ). This 


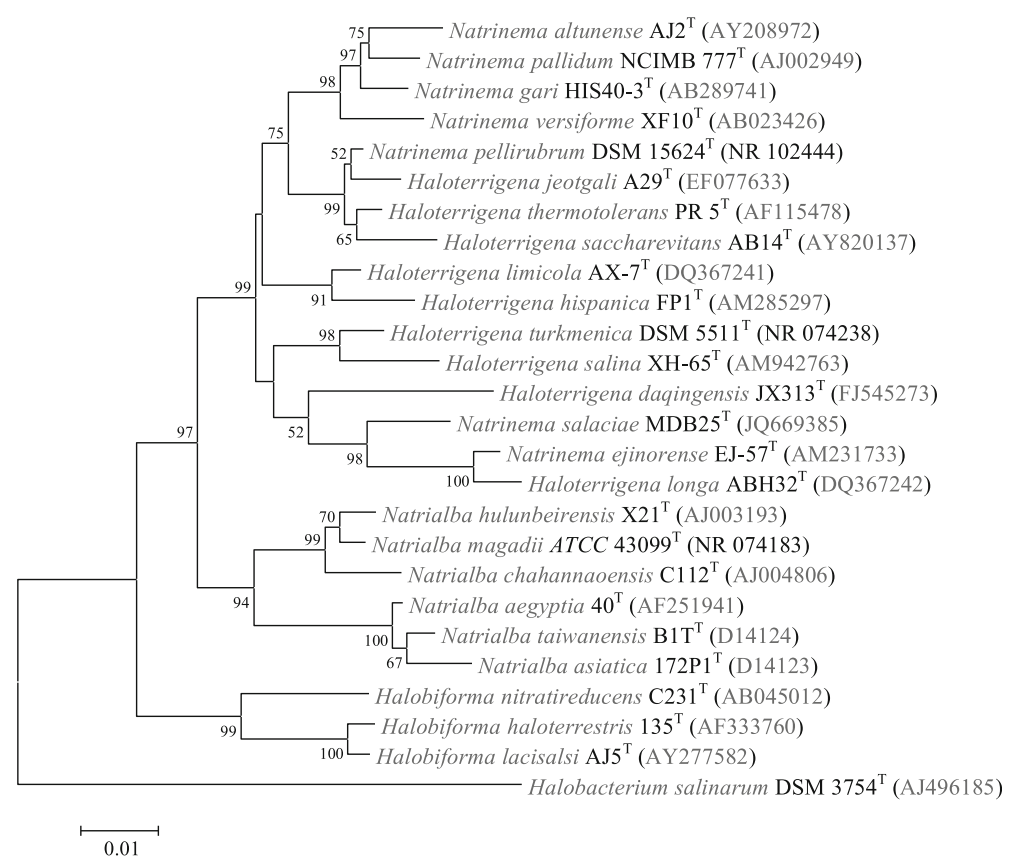

Fig. 1 Phylogenetic tree highlighting the position of the Natrinema altunense strain AJ2 ${ }^{\top}$ relative to phylogenetically closely related type strains within the family Halobacteriaceae. These sequences were aligned on the SINA Online service [40] based on SILVA SSU/LSU databases. According to the best nucleotide substitution models found by the maximum-likelihood method in MEGA6 [41], the algorithm of the Jukes-Cantor model [42] was used to calculate the evolutionary distances in the neighbour-joining ( $N J)$ method. Numbers at branch nodes refer to bootstrap values $\geq 50 \%$ (based on 1000 replicates). Halobacterium salinarum DSM 3754 (AJ496185) was used as an out-group. Bar, 0.01 substitutions per nucleotide position

strain is chemo-organotrophic and can anaerobically grow in the presence of nitrate. The strain had oxidase and catalase activity. The strain can reduce nitrate and nitrite and produce $\mathrm{N}_{2}$ gas. This strain can also hydrolyse gelatine and tweens 20,40 and 80 as well as produce $\mathrm{H}_{2} \mathrm{~S}$ from thiosulfate [3].

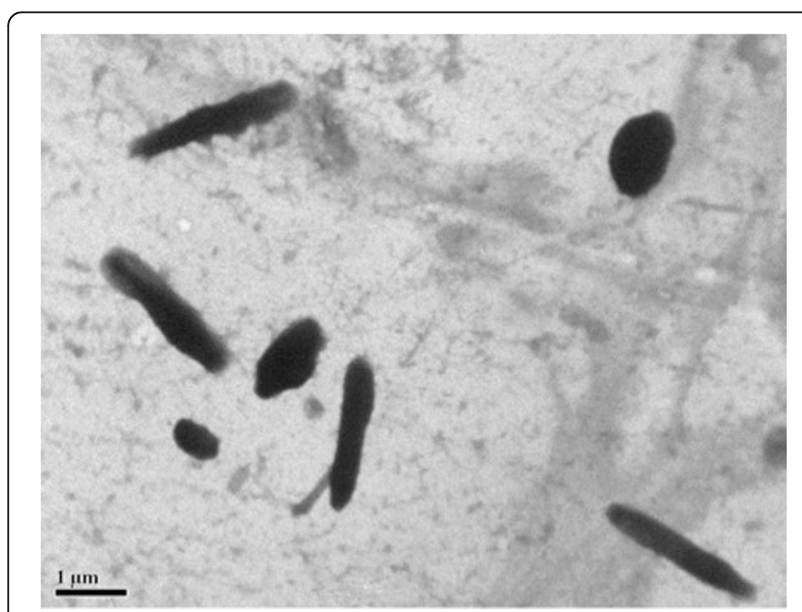

Fig. 2 Transmission electron micrograph of cells of the strain $\mathrm{A} J 2^{\top}$. Bar: $1 \mu \mathrm{m}$

\section{Genome sequencing information} Genome project history

We selected $N$. altunense $\mathrm{AJ} 2^{\mathrm{T}}$ for sequencing because its halophilic properties and high-altitude habitat may have caused interesting changes in its genome. Additionally, the five other members of genus Natrinema were sequenced and could be compared to our sequence (Table 2). This Whole Genome Shotgun project has been deposited in the DDBJ/EMBL/GenBank under the accession JNCS00000000. The version described in this paper is version JNCS00000000.1. Table 3 presents the project information and its association with MIGS version 2.0 compliance [11].

\section{Growth conditions and genomic DNA preparation}

$N$. altunense strain $\mathrm{AJ} 2^{\mathrm{T}}$ was aerobically cultivated at $37^{\circ} \mathrm{C}$ for 3 days in modified CM medium, which contained the following (per liter distilled water): $7.5 \mathrm{~g}$ Casamino acid (Bacto), $10 \mathrm{~g}$ yeast extract (OXOID), $3 \mathrm{~g}$ trisodium citrate, $2 \mathrm{~g} \mathrm{KCl}, 20 \mathrm{~g} \mathrm{MgSO}_{4} \cdot 7 \mathrm{H}_{2} \mathrm{O}$ and $200 \mathrm{~g} \mathrm{NaCl}(\mathrm{pH} \mathrm{7.2)}$. Genomic DNA was extracted according to the method described by Marmur \& Doty [12]. The cells were suspended from $250 \mathrm{ml} \mathrm{CM}$ medium and washed once with $20 \%(\mathrm{w} / \mathrm{v}) \mathrm{NaCl}$ solution. After extraction, the genomic DNA was dissolved in $1 \mathrm{ml}$ of TE buffer. The 


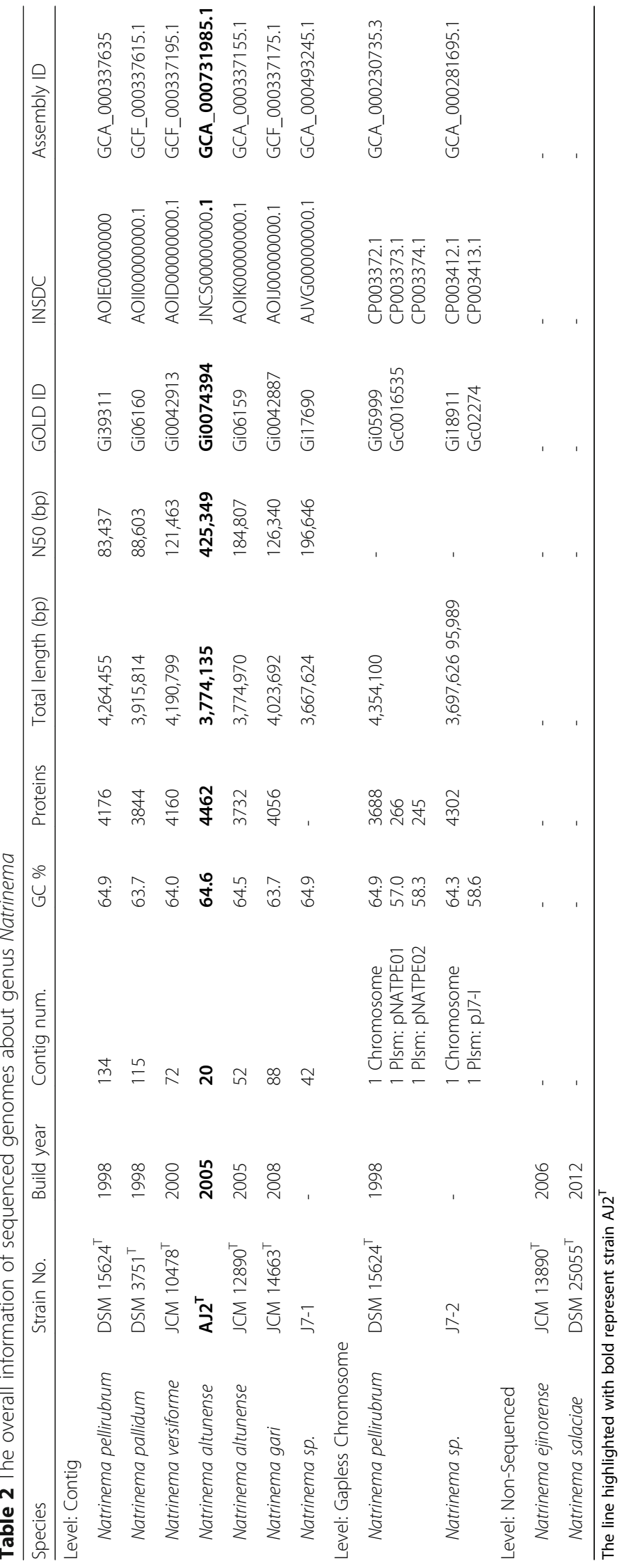


Table 3 Project information

\begin{tabular}{lll}
\hline MIGS ID & Property & Term \\
\hline MIGS-31 & Finishing quality & High-quality draft \\
MIGS-28 & Libraries used & Paired-end 2000 bp library \\
MIGS-29 & Sequencing platforms & GS FLX+ System \\
MIGS-31.2 & Fold coverage & $87 \times(2000$ bp library) \\
MIGS-30 & Assemblers & Newbler v. 2.5 \\
MIGS-32 & Gene calling method & Glimmer v3.02 \\
& Locus Tag & ALTAJ2 \\
& Genbank ID & JNCS00000000 \\
& Genbank Date of Release & July 21, 2014 \\
& GOLD ID & Gi0074394 \\
& BIOPROJECT & PRJNA248700 \\
MIGS 13 & Source Material Identifier & CGMCC 1.3731 ${ }^{\top}=J C M ~ 12890^{\top}$ \\
& Project relevance & Ecosystem \\
\hline
\end{tabular}

quality and quantity of the genomic DNA was determined by $0.7 \%$ agarose gel electrophoresis with $\lambda$-Hind III digest and $\lambda$-EcoT14 I digest DNA marker (TaKaRa, Dalian, China) as well as by the DU800 spectrophotometer (Beckman Coulter, Inc.) with the nucleotide acid analysis method. The OD260/280 of genomic DNA was 1.92 .

\section{Genome sequencing and assembly}

The next-generation genome sequencing of $N$. altunense strain $\mathrm{AJ} 2^{\mathrm{T}}$ and quality control was performed using pyrosequencing technology on a GS FLX+ system (454 Life Sciences, Roche). One library with an insert size 2,000 bp was constructed and a total of $380 \mathrm{Mb}$ clean data was obtained after filtering the adapter, artificial or low quality sequence. In other words we sequenced for a genome-wide average coverage of 87 . A total of 630,866 reads were used for assembly and produced 20 contigs using the Newbler v.2.5 (454 Life Sciences, Roche). The average contig size was 188,706 bp and the largest contig size was $837,556 \mathrm{bp}$ with the N50 size of $425,349 \mathrm{bp}$.

\section{Genome annotation}

The tRNA genes of strain $\mathrm{AJ} 2^{\mathrm{T}}$ were identified using tRNAscan-SE 1.21 [13] with an archaeal model, and its rRNA genes were found via RNAmmer 1.2 Server [14]. Other ORFs were predicted using Glimmer3 [15]. The predicted ORFs were translated and analysed using the BLASTp program (BLAST 2.2.26+) against the nonredundant, Swiss-Prot [16], Pfam [17] and COG [18] databases. Only results with an e-value smaller than $1 \times \mathrm{e}^{-5}$ were kept. For cross-validation purposes, we annotated the genome with a RAST server online [19]. KAAS [20] was used to assign the predicted amino acids into the
KEGG Pathway [21] with the BBH method. Genes with transmembrane helices were predicted using TMHMM Server v.2.0 [22]. We attempted to predict signal peptides using SignalP 4.1 Server [23], but because there were not enough experimentally confirmed signal peptides in the Uni-Prot database [23], the online server failed to provide the archaeal group model. The circular map of the genome was obtained using a local CGView application [24] with adjusted parameters (-size medium -title 'AJ2 ${ }^{\mathrm{T}}$ ' -draw_divider_rings $\mathrm{T}$-gene_decoration arc -linear circular). We uploaded the whole genome sequences in FASTA files and calculated the ANI value between every two genome sequences within the genus Natrinema and Haloterrigena on the EzGenome online server [25, 26]. Genome accession numbers for all five published Natrinema and Haloterrigena strains are listed as follows: N. altunense AJ2 (JNCS00000000); N. versiforme JCM 10478 (AOID00000000); N. pallidum DSM 3751 (AOII00000000); N. pellirubrum DSM 15624

Table 4 Number of genes associated with general COG functional categories

\begin{tabular}{|c|c|c|c|}
\hline Code & Value & $\%$ age & Description \\
\hline$J$ & 163 & 5.98 & $\begin{array}{l}\text { Translation, ribosomal structure and } \\
\text { biogenesis }\end{array}$ \\
\hline A & 1 & 0.04 & RNA processing and modification \\
\hline K & 155 & 5.69 & Transcription \\
\hline$L$ & 135 & 4.95 & Replication, recombination and repair \\
\hline B & 3 & 0.11 & Chromatin structure and dynamics \\
\hline D & 26 & 0.95 & $\begin{array}{l}\text { Cell cycle control, Cell division, } \\
\text { chromosome partitioning }\end{array}$ \\
\hline V & 39 & 1.43 & Defense mechanisms \\
\hline $\mathrm{T}$ & 120 & 4.40 & Signal transduction mechanisms \\
\hline M & 97 & 3.56 & Cell wall/membrane biogenesis \\
\hline N & 19 & 0.70 & Cell motility \\
\hline$U$ & 26 & 0.95 & Intracellular trafficking and secretion \\
\hline $\mathrm{O}$ & 123 & 4.51 & $\begin{array}{l}\text { Posttranslational modification, protein } \\
\text { turnover, chaperones }\end{array}$ \\
\hline C & 188 & 6.90 & Energy production and conversion \\
\hline G & 98 & 3.60 & Carbohydrate transport and metabolism \\
\hline$E$ & 225 & 8.26 & Amino acid transport and metabolism \\
\hline $\mathrm{F}$ & 74 & 2.72 & Nucleotide transport and metabolism \\
\hline $\mathrm{H}$ & 147 & 5.39 & Coenzyme transport and metabolism \\
\hline 1 & 112 & 4.11 & Lipid transport and metabolism \\
\hline$P$ & 183 & 6.72 & Inorganic ion transport and metabolism \\
\hline Q & 48 & 1.76 & $\begin{array}{l}\text { Secondary metabolites biosynthesis, } \\
\text { transport and catabolism }\end{array}$ \\
\hline $\mathrm{R}$ & 471 & 17.28 & General function prediction only \\
\hline S & 272 & 9.98 & Function unknown \\
\hline- & 2073 & 46.46 & Not in COGs \\
\hline
\end{tabular}

The total is based on the total number of protein coding genes in the genome 
(CP003372); N. gari JCM 14663 (AOIJ00000000); $H$. thermotolerans DSM 11522 (AOIR00000000); H. salina JCM 13891 (AOIS00000000); H. limicola JCM 13563 (AOIT00000000); H. turkmenica DSM 5511 (CP001860); and $H$. jeotgali A29 (JDTG00000000). Unless otherwise specified, we used default parameters for all software.

\section{Genome properties}

This high-quality draft genome sequence of $N$. altunense $\mathrm{AJ} 2^{\mathrm{T}}$ revealed a genome size of $3,774,135$ bp (all 20 contigs length, $64.56 \%$ GC content). We predicted 4517 genes; 4462 are protein-coding sequences. A total of 3792 protein-coding genes $(83.95 \%)$ were assigned to a putative function or as hypothetical proteins. We also found 52 tRNA genes (removed 1 Pseudo tRNA) and 3 rRNA genes (one $23 \mathrm{~S}$ rRNA, one $16 \mathrm{~S}$ rRNA and one 5 S rRNA). We assigned 1929 protein-coding genes (42.71\%) to Pfam domains and categorized 2255 (49.92\%) protein-coding genes into COGs functional groups (Table 4 and Fig. 3). This genome has a gene content redundancy of $36.11 \%$, and there are 1631 protein coding genes belonging to 540 paralog clusters. The genomic
ANI values within the Natrinema and Haloterrigena genera are listed in Table 5. In the Richter \& Rosselló-Móra report, the proposed ANI cut-off for the species boundary is at $95 \sim 96 \%$ [25]. According to our calculation data, the ANI values between any two species of Natrinema with published genome sequences were lower than 93.2\% and this value was observed between strains $\mathrm{AJ} 2^{\mathrm{T}}$ and Natrinema pallidum DSM $3751^{\mathrm{T}}$. We can also easily observe that $N$. pellirubrum show higher ANI values (>95\%) with $H$. thermotolerans DSM $11522^{\mathrm{T}}$ (95.4\%) and $H$. jeotgali $\mathrm{A} 29^{\mathrm{T}}(95.2 \%)$. These data are also identical to the phylogenetic distance in the 16S rRNA maximum-likelihood tree (Fig. 1). In the tree, the other two strains $N$. salaciae MDB25 ${ }^{\mathrm{T}}$ and $N$. ejinorense $\mathrm{EJ}-57^{\mathrm{T}}$, which are in the same clade as genus Haloterrigena, lack of genome information for considering their ANI values in this study.

\section{Insights from the genome sequence}

We compared all sequenced strains in the genus Natrinema with strain $\mathrm{AJ} 2^{\mathrm{T}}$ according to the contig numbers, $\mathrm{G}+\mathrm{C}$ content, predicted protein numbers,

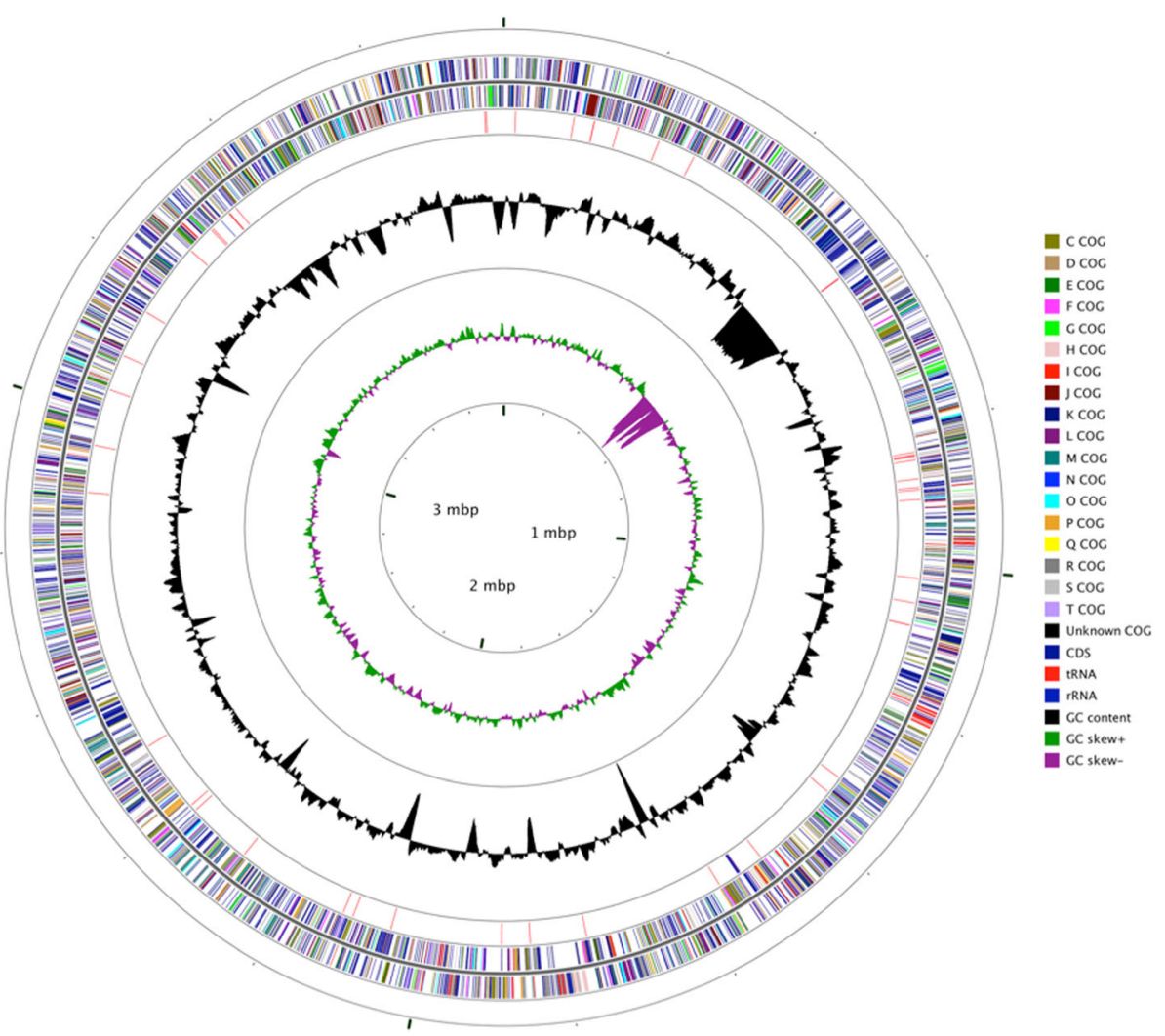

Fig. 3 Graphical circular map of the genome of $N$. altunense AJ2 ${ }^{\top}$. Labelling from outside to the center: circle 1, CDSs on the forward strand (coloured by COG categories); circle 2, CDSs on the reverse strand (coloured by COG categories); circle 3, RNA genes (tRNAs red and rRNAs blue); circle 4, G + C content (peaks out/inside the circle indicate values higher or lower than the average G + C content 64.65\%, respectively); circle 5, GC skew (calculated as $(G-C) /(G+C)$ using a window size of 10000 and step of 100, green/purple peaks out/inside the circle indicates values higher or lower than average GC skew value $(-0.0047)$, respectively); and circle 6, Genome size (Mbp) 
Table 5 ANI values between genome pairs within genus Natrinema and Haloterrigena

\begin{tabular}{|c|c|c|c|c|c|c|c|c|c|c|}
\hline$\rightarrow$ & N. altunense & N. versiforme & N. pallidum & N. pellirubrum & N. gari & H. thermotolerans & H. salina & H. limicola & H. turkmenica & H. jeotgali \\
\hline N. altunense & - & $83.50 \%$ & $93.22 \%$ & $82.89 \%$ & $92.75 \%$ & $82.82 \%$ & $79.84 \%$ & $80.99 \%$ & $79.94 \%$ & $82.89 \%$ \\
\hline N. versiforme & $83.09 \%$ & - & $82.96 \%$ & $82.40 \%$ & $82.92 \%$ & $82.31 \%$ & $80.41 \%$ & $80.90 \%$ & $80.20 \%$ & $82.37 \%$ \\
\hline N. pallidum & $93.21 \%$ & $82.75 \%$ & - & $82.75 \%$ & $91.65 \%$ & $82.74 \%$ & $79.78 \%$ & $80.93 \%$ & $79.70 \%$ & $82.79 \%$ \\
\hline N. pellirubrum & $83.00 \%$ & $82.36 \%$ & $82.98 \%$ & - & $82.69 \%$ & $95.39 \%$ & $80.00 \%$ & $80.83 \%$ & $80.20 \%$ & $95.16 \%$ \\
\hline N. gari & $92.82 \%$ & $82.59 \%$ & $91.89 \%$ & $82.39 \%$ & - & $82.48 \%$ & $79.63 \%$ & $80.69 \%$ & $79.75 \%$ & $82.65 \%$ \\
\hline H. thermotolerans & $82.65 \%$ & $82.29 \%$ & $82.35 \%$ & $95.49 \%$ & $82.33 \%$ & - & $80.03 \%$ & $80.64 \%$ & $80.30 \%$ & $97.36 \%$ \\
\hline H. salina & $79.45 \%$ & $79.87 \%$ & $79.38 \%$ & $79.91 \%$ & $79.13 \%$ & $79.91 \%$ & - & $78.77 \%$ & $90.60 \%$ & $79.96 \%$ \\
\hline H. limicola & $80.98 \%$ & $81.15 \%$ & $80.89 \%$ & $81.12 \%$ & $80.81 \%$ & $80.88 \%$ & $79.43 \%$ & - & $79.49 \%$ & $81.34 \%$ \\
\hline H. turkmenica & $79.69 \%$ & $80.25 \%$ & $79.42 \%$ & $80.22 \%$ & $79.41 \%$ & $80.12 \%$ & $91.13 \%$ & $79.14 \%$ & - & $80.29 \%$ \\
\hline H. jeotgali & $82.56 \%$ & $82.42 \%$ & $82.79 \%$ & $95.14 \%$ & $82.43 \%$ & $97.41 \%$ & $80.11 \%$ & $80.81 \%$ & $80.35 \%$ & - \\
\hline
\end{tabular}

The calculated genomic sequence used: N. altunense AJ2 (JNCS00000000); N. versiforme JCM 10478 (AOID00000000); N. pallidum DSM 3751 (AOII00000000); N. pellirubrum DSM 15624 (CP003372); N. gari JCM 14663 (AOIJ00000000); H. thermotolerans DSM 11522 (AOIR00000000); H. salina JCM 13891 (AOIS00000000); H. limicola JCM 13563 (AOIT00000000); H. turkmenica DSM 5511 (CP001860); H. jeotgali A29 (JDTG00000000)

total length and N50, which are listed below (Table 6). The other relevant genomic features were listed in Table 7. According to the chemotaxonomic information and characteristic features of strain $\mathrm{AJ}^{\mathrm{T}}$ that was mentioned before, the strain contains a flagellin domain protein in its genomic features to support cell motility. It also has DNA repair systems for protecting the stability of its genome from potential damage caused by UV radiation. Additionally, the energy converting system and light-driven pumps are introduced below.

\section{Light-driven pumps}

The strict living environment and lack of nutritious carbon/nitrogen sources cause diversification of metabolic pathway strain $\mathrm{AJ} 2^{\mathrm{T}}$ and similar halophilic archaea, as well

Table 6 Genome statistics

\begin{tabular}{lll}
\hline Attribute & Value & \% of total \\
\hline Genome Size (bp) & $3,774,135$ & - \\
DNA coding (bp) & $3,316,088$ & 87.86 \\
DNA G + C (bp) & $2,436,432$ & 64.56 \\
DNA scaffolds & 20 & - \\
Total genes & 4517 & - \\
Protein-coding genes & 4462 & 98.78 \\
RNA genes & 55 & 1.22 \\
Pseudo genes & - & - \\
Genes in internal clusters & 540 & 11.95 \\
Genes with function prediction & 2215 & 49.04 \\
Genes assigned to CoGs & 2255 & 49.92 \\
Genes with Pfam domains & 1929 & 42.71 \\
Genes with signal peptides & - & - \\
Genes with transmembrane helices & 879 & 19.46 \\
CRISPR repeats & - & - \\
\hline
\end{tabular}

as for haloarchaea, with more resources. Strain $\mathrm{AJ} 2^{\mathrm{T}}$ might use sunlight to produce ATP. We predicted the existence of two light-energy-converting system genes in the $\mathrm{AJ} 2^{\mathrm{T}}$ genome, namely bop and hop. The two encode homologous proteins bacteriorhodopsin and halorhodopsin, respectively. Bacteriorhodopsin and halorhodopsin share $36 \%$ of the amino acid residues in the transmembrane part and 19\% in the surface connecting loops [27].

Bacteriorhodopsin is an integral membrane protein, called purple membrane, located in the archaea cell membrane, and it acts as a light-driven proton pump. It is mainly found in the Halobacteriaceae family $[28,29]$. It captures and uses light energy to move protons out of the cell membrane, resulting in a proton electrochemical gradient. Subsequently, the gradient is converted into chemical energy through ATP synthesis or is used to fuel flagellar motility and other energy requiring processes [30]. We obtained the complete bop gene (AY279548, JQ406920, and AFB77278) in the strain $\mathrm{AJ} 2^{\mathrm{T}}$ by the LPA method. We then successfully expressed the $\mathrm{AJ}^{\mathrm{T}}$ bacteriorhodopsin protein in E.coli BL21 with recombinant pET28a plasmid. This result indicates that the prediction of the bop gene is correct. Halorhodopsin is a light-activated chloride pump that is also found in archaea. It utilizes light to transfer the chloride ions into the cytoplasm and increase the electrochemical potential of the proton gradient [31]. This gene is extremely important for salty environment tolerance and, by reporting the existence of a hop gene in the $N$. altunense strain $\mathrm{AJ} 2^{\mathrm{T}}$, we shed light on the potential mechanism of its adaptation to high salinity.

Bacteriorhodopsin, halorhodopsin and several related bacterio-opsin activator HTH domain proteins were also found in the other sequenced type strains $N$. pellirubrum, N. pallidum, N. gari and strain Natrinema sp. J72 (listed in Table 8). As the haloarchaea species of the genus Natrinema typically live in similar environment, 
Table 7 The relevance characteristics with genomic features annotation

\begin{tabular}{|c|c|c|c|c|c|}
\hline Relevant characteristics & ID & Contig & Position & Strand & Annotation \\
\hline \multirow[t]{2}{*}{ Tween degradation } & AJ2_rast_231 & 1 & 198927:200015 & + & esterase/lipase \\
\hline & AJ2_rast_522 & 1 & 476323:477450 & - & putative esterase \\
\hline \multirow[t]{2}{*}{ Thiosulfate degradation } & AJ2_rast_3344 & 11 & 30688:31554 & - & $\begin{array}{l}\text { thiosulfate sulfurtransferase } 2 C \\
\text { rhodanese (EC 2.8.1.1) }\end{array}$ \\
\hline & AJ2_rast_3346 & 11 & $31834: 32646$ & + & thiosulfate sulfurtransferase (EC:2.8.1.1) \\
\hline \multirow[t]{2}{*}{$\mathrm{H}_{2} \mathrm{O}_{2}$ degradation } & AJ2_rast_1204 & 2 & 332019:334157 & + & catalase (EC 1.11.1.6)/Peroxidase (EC 1.11.1.7) \\
\hline & AJ2_rast_3782 & 16 & 4816:5718 & - & catalase (EC:1.11.1.6) \\
\hline \multirow[t]{5}{*}{ Nitrous oxide reductase } & AJ2_rast_1974 & 4 & 104337:105296 & - & $\begin{array}{l}\text { nitrous oxide reductase maturation } \\
\text { transmembrane protein NosY }\end{array}$ \\
\hline & AJ2_rast_2203 & 4 & $324166: 325008$ & + & $\begin{array}{l}\text { nitrous oxide reductase maturation } \\
\text { transmembrane protein NosY }\end{array}$ \\
\hline & AJ2_rast_3199 & 10 & 18205:19152 & - & $\begin{array}{l}\text { nitrous oxide reductase maturation } \\
\text { transmembrane protein NosY }\end{array}$ \\
\hline & AJ2_rast_3201 & 10 & 20059:21438 & - & $\begin{array}{l}\text { nitrous oxide reductase maturation } \\
\text { protein NosD }\end{array}$ \\
\hline & AJ2_rast_3203 & 10 & 22285:24204 & - & nitrous-oxide reductase (EC 1.7.99.6) \\
\hline \multirow[t]{4}{*}{ Motility } & AJ2_rast_1043 & 2 & 171217:173058 & + & flagella-related protein Flal \\
\hline & AJ2_rast_1170 & 2 & 296018:296341 & + & chemotaxis regulator CheY \\
\hline & AJ2_rast_1825 & 3 & 392764:394281 & + & conserved flagella cluster protein \\
\hline & AJ2_rast_2104 & 4 & 230767:231792 & - & $\begin{array}{l}\text { signal peptidase2C type IV - } \\
\text { prepilin/preflagellin }\end{array}$ \\
\hline \multirow[t]{4}{*}{ DNA repair } & AJ2_rast_1703 & 3 & 284669:285400 & + & $\begin{array}{l}\text { DNA repair and recombination } \\
\text { protein RadB }\end{array}$ \\
\hline & AJ2_rast_2261 & 4 & 382800:384209 & - & $\begin{array}{l}\text { single-stranded-DNA-specific } \\
\text { exonuclease RecJ (EC 3.1.--) }\end{array}$ \\
\hline & AJ2_rast_2296 & 4 & 413891:414922 & + & $\begin{array}{l}\text { DNA repair and recombination } \\
\text { protein RadA }\end{array}$ \\
\hline & AJ2_rast_2880 & 8 & 16958:18862 & + & RecJ like exonuclease \\
\hline
\end{tabular}

this type of bacteriorhodopsin/halorhodopsin-based phototrophy can help them adapt to extremely hypersaline and oligotrophic niches.

\section{Conclusions}

The genome of strain $\mathrm{AJ} 2^{\mathrm{T}}$ did not have the longest length in the sequenced strains of Natrinema, but it had most predicted proteins. Meanwhile, the assembled result in the strain $\mathrm{AJ} 2^{\mathrm{T}}$ had the lowest contig numbers and largest N50 length. This indicated the larger size of the library (2000 bp library) and the longer read length (up to $1000 \mathrm{bp}$ with an average read length $603 \mathrm{bp}$ ) may significantly improve the assembling quality.

Our genomic analysis of strain $\mathrm{AJ} 2^{\mathrm{T}}$ shed light on its ability to survive in the Ayakekum salt lake of Altun Mountain National Nature Reserve in Xinjiang, China. This lake is regarded as a relatively extreme environment with low nutrient levels, a cool temperature, strong sunlight and high-altitude. We found evidence for an alternative energy converting system to gain a supplementary

Table 8 Bacteriorhodopsin and halorhodopsin in the genomes of genus Natrinema

\begin{tabular}{|c|c|c|c|c|c|}
\hline \multirow[t]{2}{*}{ Species } & \multirow[t]{2}{*}{ Strain } & \multicolumn{2}{|c|}{ Bacteriorhodopsin } & \multicolumn{2}{|c|}{ Halorhodopsin } \\
\hline & & Size/aa & Accession No. & Size/aa & Accession No. \\
\hline N. pellirubrum & DSM $15624^{\top}$ & 223 & WP_006180343 & 281 & WP_006179856 \\
\hline N. pallidum & DSM $3751^{\top}$ & 223 & WP_006186147 & 282 & WP_006185564 \\
\hline N. altunense $e^{a}$ & $\mathrm{AJ} 2^{\top}$ & 223 & AFB77278 & 285 & KY435894 \\
\hline N. gari & JCM $14663^{\top}$ & 223 & WP_008455435 & 282 & WP_008453746 \\
\hline Natrinema sp. & $\mathrm{J} 7-2$ & 223 & YP_006542121 & 278 & YP_006540994 \\
\hline
\end{tabular}

${ }^{a}$ This data line represents the closest output obtained using BLASTp program against the nr database. These two genes are on contig 1 (position:629096-629767, forward strand) and contig 3 (position:389528-390385, forward strand) of the genome of strain $A J 2^{\top}$, respectively 
energy source. The energy converting system, bacteriorhodopsin, halorhodopsin and HTH domain proteins, were also found in comparison it to all other sequenced strains in the genus Natrinema and they mostly share this energy-producing pathway.

More intensive study and data-mining need to be considered in genomes of the genus Natrinema or another halophilic archaeon. Then, we might find some reasons for these ancient archaeon to have so much vitality and prosperity in extreme environment on planet Earth.

\section{Abbreviations}

ANI: Average Nucleotide Identity; BBH: Bi-directional Best Hit; KAAS: KEGG Automatic Annotation Server; LPA: Ligation-mediated PCR Amplification; Plsm: Plasmid

\section{Acknowledgements}

We would like to thank Qi-Lan Wang for help with coding custom scripts and performing gene annotations. We also thank Chenling Antelope for language editing and her advice about the phylogenetic analysis. This work was supported by the National Natural Science Foundation of China (Project No. 31170001, No. 31470005, No. 41276173), Zhejiang Provincial Natural Science Foundation of China (No. LQ13D060002) and Scientific Research Fund of the Second Institute of Oceanography, SOA (No. JT1305).

\section{Authors' contributions}

Hong Cheng designed and performed experiments, analysed the data and wrote the paper; Ying-Yi Huo performed experiments and edited the paper Jing Hu collected and analysed genome data; and Xue-Wei Xu and Min Wu conceived of the experiments and wrote the paper. All authors read and approved of the final manuscript.

\section{Competing interests}

The authors declare that they have no competing interests.

Received: 21 May 2015 Accepted: 5 December 2016

Published online: 01 March 2017

\section{References}

1. McGenity TJ, Gemmell RT, Grant WD. Proposal of a new halobacterial genus Natrinema gen. nov., with two species Natrinema pellirubrum nom. nov. and Natrinema pallidum nom. nov. Int J Syst Bacteriol. 1998:48:1187-96.

2. Xin H, Itoh T, Zhou P, Suzuki K-i, Kamekura M, Nakase T. Natrinema versiforme sp. nov., an extremely halophilic archaeon from Aibi salt lake Xinjiang, China. Int J Syst Evol Microbiol. 2000;50:1297-303.

3. Xu X-W, Ren P-G, Liu S-J, Wu M, Zhou P-J. Natrinema altunense sp. nov., an extremely halophilic archaeon isolated from a salt lake in Altun Mountain in Xinjiang, China. Int J Syst Evol Microbiol. 2005;55:1311-4.

4. Tapingkae W, Tanasupawat S, Itoh T, Parkin KL, Benjakul S, Visessanguan W, Valyasevi R. Natrinema gari sp. nov., a halophilic archaeon isolated from fish sauce in Thailand. Int J Syst Evol Microbiol. 2008;58:2378-83.

5. Castillo A, Gutiérrez M, Kamekura M, Xue Y, Ma Y, Cowan D, Jones B, Grant W, Ventosa A. Natrinema ejinorense sp. nov., isolated from a saline lake in Inner Mongolia, China. Int J Syst Evol Microbiol. 2006;56:2683-7.

6. Albuquerque L, Taborda M, La Cono V, Yakimov M, da Costa MS. Natrinema salaciae sp. nov., a halophilic archaeon isolated from the deep, hypersaline anoxic Lake Medee in the Eastern Mediterranean Sea. Syst Appl Microbiol. 2012;35:368-73

7. Pagani I, Liolios K, Jansson J, Chen I-MA, Smirnova T, Nosrat B, Markowitz VM Kyrpides NC. The Genomes OnLine Database (GOLD) v. 4: status of genomic and metagenomic projects and their associated metadata. Nucleic Acids Res. 2012:40:D571-9

8. Kim B-C, Poo H, Lee KH, Kim MN, Park D-S, Oh HW, Lee JM, Shin K-S Simiduia areninigrae sp. nov., an agarolytic bacterium isolated from sea sand. Int J Syst Evol Microbiol. 2012;62:906-11.

9. Tindall B. Taxonomic problems arising in the genera Haloterrigena and Natrinema. Int J Syst Evol Microbiol. 2003;53:1697-8.
10. Minegishi H, Kamekura M, Itoh T, Echigo A, Usami R, Hashimoto T. Further refinement of the phylogeny of the Halobacteriaceae based on the fulllength RNA polymerase subunit B'(rpoB') gene. Int J Syst Evol Microbiol. 2010;60:2398-408

11. Field D, Garrity G, Gray T, Morrison N, Selengut J, Sterk P, Tatusova T, Thomson N, Allen MJ, Angiuoli SV, et al. The minimum information about a genome sequence (MIGS) specification. Nat Biotechnol. 2008;26:541-7.

12. Marmur J, Doty P. Thermal renaturation of deoxyribonucleic acids. J Mol Biol. 1961:3.585-94.

13. Schattner P, Brooks AN, Lowe TM. The tRNAscan-SE, snoscan and snoGPS web servers for the detection of tRNAs and snoRNAs. Nucleic Acids Res. 2005;33:W686-9.

14. Lagesen $\mathrm{K}$, Hallin $\mathrm{P}$, Rødland EA, Stærfeldt H-H, Rognes T, Ussery DW. RNAmmer: consistent and rapid annotation of ribosomal RNA genes. Nucleic Acids Res. 2007:35:3100-8.

15. Delcher AL, Bratke KA, Powers EC, Salzberg SL. Identifying bacterial genes and endosymbiont DNA with Glimmer. Bioinformatics. 2007:23:673-9.

16. Boeckmann B, Bairoch A, Apweiler R, Blatter M-C, Estreicher A, Gasteiger E, Martin MJ, Michoud K, O'Donovan C, Phan I. The SWISS-PROT protein knowledgebase and its supplement TrEMBL in 2003. Nucleic Acids Res. 2003:31:365-70.

17. Finn RD, Bateman A, Clements J, Coggill P, Eberhardt RY, Eddy SR, Heger A, Hetherington K, Holm L, Mistry J, et al. Pfam: the protein families database. Nucleic Acids Res. 2014;42:D222-30.

18. Tatusov RL, Natale DA, Garkavtsev IV, Tatusova TA, Shankavaram UT, Rao BS, Kiryutin B, Galperin MY, Fedorova ND, Koonin EV. The COG database: new developments in phylogenetic classification of proteins from complete genomes. Nucleic Acids Res. 2001:29:22-8.

19. Aziz RK, Bartels D, Best AA, DeJongh M, Disz T, Edwards RA, Formsma K, Gerdes S, Glass EM, Kubal M. The RAST Server: rapid annotations using subsystems technology. BMC Genomics. 2008;9:75

20. Moriya $Y$, Itoh M, Okuda S, Yoshizawa AC, Kanehisa M. KAAS: an automatic genome annotation and pathway reconstruction server. Nucleic Acids Res. 2007;35:W182-5.

21. Kanehisa M, Goto S. KEGG: kyoto encyclopedia of genes and genomes. Nucleic Acids Res. 2000;28:27-30.

22. Krogh A, Larsson B, Von Heijne G, Sonnhammer EL. Predicting transmembrane protein topology with a hidden Markov model: application to complete genomes. J Mol Biol. 2001;305:567-80

23. Petersen TN, Brunak S, von Heijne G, Nielsen H. SignalP 4.0: discriminating signal peptides from transmembrane regions. Nat Methods. 2011;8:785-6.

24. Stothard P, Wishart DS. Circular genome visualization and exploration using CGView. Bioinformatics. 2005:21:537-9.

25. Richter M, Rosselló-Móra R. Shifting the genomic gold standard for the prokaryotic species definition. Proc Natl Acad Sci. 2009;106:19126-31.

26. Goris J, Konstantinidis KT, Klappenbach JA, Coenye T, Vandamme P, Tiedje JM. DNA-DNA hybridization values and their relationship to whole-genome sequence similarities. Int J Syst Evol Microbiol. 2007;57:81-91.

27. Blanck A, Oesterhelt D. The halo-opsin gene. II. Sequence, primary structure of halorhodopsin and comparison with bacteriorhodopsin. EMBO J. 1987;6: 265-73.

28. Dunn R, McCoy J, Simsek M, Majumdar A, Chang SH, RajBhandary UL, Khorana HG. The bacteriorhodopsin gene. Proc Natl Acad Sci. 1981;78: $6744-8$

29. Trivedi S, Prakash Choudhary O, Gharu J. Different proposed applications of bacteriorhodopsin. Recent Pat DNA Gene Seq. 2011;5:35-40.

30. Oesterhelt D, Stoeckenius W. Functions of a new photoreceptor membrane. Proc Natl Acad Sci. 1973;70:2853-7.

31. Sharma AK, Walsh DA, Bapteste E, Rodriguez-Valera F, Doolittle WF, Papke RT. Evolution of rhodopsin ion pumps in haloarchaea. BMC Evol Biol. 2007;7:79.

32. Woese $\mathrm{CR}$, Kandler $\mathrm{O}$, Wheelis ML. Towards a natural system of organisms: proposal for the domains Archaea, Bacteria, and Eucarya. Proc Natl Acad Sci. 1990:87:4576-9.

33. Validation of publication of new names and new combinations previously effectively published outside the IJSEM. International Journal of Systematic and Evolutionary Microbiology. Int J Syst Evol Microbiol. 2002;52:685-690. http://ijs.microbiologyresearch.org/content/journal/ijsem/10.1099/0020771352-3-685.

34. Garrity GM, Holt JG. Phylum All. Euryarchaeota phy. nov. In: Boone DR, Castenholz RW, Garrity GM, editors. Bergey's Manual ${ }^{\circledR}$ of Systematic 
Bacteriology, The Archaea and the deeply branching and phototrophic Bacteria, vol. 1. Secondth ed. New York: Springer; 2001. p. 211-355.

35. Grant WD, Larsen H. Group III. Extremely halophilic archaeobacteria. Order Halobacteriales ord. nov. In: Staley JT, Bryant MP, Pfennig N, Holt JG, editors. Bergey's Manual ${ }^{\circledR}$ of Systematic Bacteriology, vol. 3. firstth ed. Baltimore: The Williams \& Wilkins Co; 1989. p. 2216-8.

36. Validation of the Publication of New Names and New Combinations Previously Effectively Published Outside the IJSB: List No. 31. Int J Syst Bacteriol. 1989:39:495-497.

37. Skerman VBD, McGowan V, Sneath PHA. Approved Lists of Bacterial Names. Int J Syst Bacteriol. 1980;30:225-420.

38. Gibbons NE. Family V. Halobacteriaceae Fam. nov. In: Buchanan RE, Gibbons $\mathrm{NE}$, editors. Bergey's Manual of Determinative Bacteriology. eightth ed. Baltimore: The Williams \& Wilkins Co; 1974. p. 269.

39. Ashburner M, Ball CA, Blake JA, Botstein D, Butler H, Cherry JM, Davis AP, Dolinski K, Dwight SS, Eppig JT, et al. Gene ontology: tool for the unification of biology. Gene Ontol Consortium Nat Genet. 2000;25:25-9.

40. Pruesse E, Peplies J, Glöckner FO. SINA: Accurate high-throughput multiple sequence alignment of ribosomal RNA genes. Bioinformatics. 2012;28:1823-9.

41. Tamura K, Stecher G, Peterson D, Filipski A, Kumar S. MEGA6: molecular evolutionary genetics analysis version 6.0. Mol Biol Evol. 2013;30:2725-9.

42. Jukes TH, Cantor CR. Mammalian Protein Metabolism: Evolution of protein molecules. 3rd ed. New York: Academic; 1969. p. 21-132.

\section{Submit your next manuscript to BioMed Central and we will help you at every step:}

- We accept pre-submission inquiries

- Our selector tool helps you to find the most relevant journal

- We provide round the clock customer support

- Convenient online submission

- Thorough peer review

- Inclusion in PubMed and all major indexing services

- Maximum visibility for your research

Submit your manuscript at www.biomedcentral.com/submit 